\title{
Introduction by the Guest Editor
}

\author{
Jeffrey Bloechl
}

(C) Springer Science+Business Media Dordrecht 2014

It is Heidegger who asks what there is to be thought after the end of metaphysics, and indeed his own work is never far from a response to the question. This is neither to say that there is only one such response, nor even to suppose that Heidegger's thinking provides only one response. To be sure, the origin of the question is not difficult to identify. Metaphysics, as the grounding of known beings in some anterior or first being, comes to its end as thinking becomes capable of grasping it as a sum of relations. This occurs when thinking is awakened to the difference between inquiring about beings (Seiende), including the first being, and asking the question of the meaning of Being (Sein). In an important sense, then, the "end" of metaphysics coincides with the appearing of its place within a more primordial horizon. Attending more closely to the historical configuration of this metaphysics, Heidegger often concentrates on the recurrence, or else the persistence, of an urge in thinking to stabilize itself by appeal to unity. Already before Sein und Zeit, this appeal is approched by way of a claim that Dasein does not rest on any prior cause, but rather comprehends all causal relations in a thrownness in the world that is also an abyss of ground. Subsequent texts seem only to pursue the implications of this claim, while working out the nature of a thinking that would be guided by it.

Yet if we therefore agree that after the end of metaphysics there remains a thinking that suspends any urge to stabilize itself in a commitment to founded unity, we have come only to a formal definition of what Heidegger sometimes calls "thoughtful thinking." Does thoughtful thinking only consider and perhaps supply clarification of the necessary unity of metaphysical thinking? Or does it already move as if without possibility of recourse to unity? These alternatives are far apart. Their difference suggests to us that if we ask Heidegger what is to be thought after

\footnotetext{
J. Bloechl ( $($ )

Boston College, Boston, MA, USA

e-mail: jeffrey.bloechl@bc.edu
} 
the end of metaphysics is, we are led inevitably to ask ourselves how we are to read his texts. It is probably too much to suppose that Heidegger begins on his way with a clear formulation of the end of metaphysics in the terms that we have just invoked. This certainly does not mean that Sein und Zeit, for example, has no relation to the topic, but only that Heidegger's mature view of the latter emerged only gradually, and - though there is considerable disagreement about the specifics—with some adjustments. With this in mind, we might briefly recall distinct approaches to the task of understanding the relation among Heidegger's texts.

From the perspective of an encyclopedic reading of the available texts, William J. Richardson detects a basic unity in Heidegger's question, which in its bare form does not change even as the thinker recognizes new complications and pursues numerous related themes and problems. This unity in the questioning insures the inner consistency of an oeuvre. Heidegger's texts exhibit the course taken by a thinking that is renewed and enriched by each successive exercise. To be sure, the phenomenological method of the texts from the 1920s no longer explicitly defines a thinking that is increasingly meditative as much as it is investigative, but this difference is arguably the outcome of a progression rather than a break and a new beginning. On occasion, Heidegger suggests that what Sein und Zeit could not think comes into view only in and through what it is able to think. ${ }^{1}$ Nothing prevents us from taking the same view of method. And this possibility reminds us of the strongly autobiographical dimension of Heidegger's celebrated remark that "what lasts in thinking is the way." 2

But if the way of Heidegger's thinking is unified essentially by its response to the single question of the meaning of Being, then it is also unsettled and put in movement by the withdrawal of its theme from any topos. This has been emphasized by Otto Poggeler, who has concentrated on showing that the thinking that is in movement is not necessarily therefore a thinking of multiple and irreconcilable thoughts. ${ }^{3}$ The thinking that recognizes the end of metaphysics comes to know that Being is accessible only in the unconcealment that is also concealment. The way of this thinking thus sojourns in the neighborhood of Being, or perhaps pursues the traces by which it lets itself be seen without ceasing to be itself.

Does all of this mean that a deepening appreciation of what is required to ask about the meaning of Being eventually requires abandonment of the phenomenological method? The question reminds us that phenomenology itself, according to its essential wish to let be seen what gives itself to be seen and as it gives itself to be seen, has always been committed to correlation between object and method. Which method would be adequate to the givenness of Being? The task no doubt stretches phenomenology to its limit, at which point it would be called upon to proceed without original commitment either to subjects or to objects. It is certainly tempting to interpret what the first of the Bremen Lectures calls the "fourfold" (das Geviert) in this way: humans dwell in the world, which is itself the unity of the fourfold of

\footnotetext{
1 E.g., in his "Foreward" to W.J. Richardson, SJ, Heidegger. Through Phenomenology to Thought (New York: Fordham University Press, 2003), p. XVIII/XIX.

2 M. Heidegger, Unterwegs zur Sprache (Pfullingen: Gunter Neske, 1959), p. 99.

3 O. Poggeler, Der Denkweg Martin Heideggers (Pfullingen: Gunter Neske, 1963), p. 9.
} 
earth, sky, mortals and gods that abides in the thingness of a thing; and this dwelling, we know from other texts, is our relation to Being. ${ }^{4}$ Here, of course, we would see a unity that is no longer that of metaphysical principles such as Heidegger identifies in classical metaphysics. But then if the thingness of things is to be included under what must be thought after the end of metaphysics, the thinking in question is to be done most notably without recourse to any foundation such as he most often associates with Christianity. Whether or not Christian thought always answers to Heidegger's account of it, we might nonetheless suppose, with Didier Franck, ${ }^{5}$ that the entirety of his way has included a constant discourse with that powerful current of western culture.

These few ways of interpreting Heidegger, and indeed of understanding the relation between his texts, have in common the thought that it is the resistance of his topic to successive modes of inquiry that drives the movement of his thinking. Inevitably, this raises the thought that the later texts, whatever their debt to the earlier ones, see more deeply into that topic - that is to say, for example, manage to abide more closely to Being. The implied call for a retrospective study of the earlier texts has been answered by Reiner Schürmann. ${ }^{6}$ In the present context, Schürmann's perspective is especially interesting because in some respects it closes a circle with some of the position taken much earlier by Richardson and Poggeler. The fact that Sein und Zeit set itself a task for which it was not yet prepared will have been the early expression of a deep intuition into the relation between Being and thinking that is worked out only slowly along a single way, through a series or array of exercises, each attempting to renew and advance beyond the previous ones. Thinking is to wean itself away from its own urge for reliance on stabilizing principles, until approaching a capacity to think, and in thinking also enact, what Schürmann is willing to call "anarchy." After the end of metaphysics, it thus remains for us to think the solidarity of thinking and acting without recourse to a foundation on which thinking might claim the right to rest and survey the polemos.

The present essays do not necessarily restrict themselves to the parameters of the foregoing remarks, but it can be useful to consider them in their vicinity. The first two plainly resume the debate over quite how to understand Heidegger's method in relation to his stated theme. In Thomas Sheehan's "What, After All, Was Heidegger About?," the philosopher never ceases to be a phenomenologist, even as his pursuit of the Seinsfrage came to focus on what in the 1930s he begins to call "the clearing" (die Lichtung) in which the Being of things is given as their meaningful presence. Developed in terms of five closely-related theses, Sheehan proposes nothing short of a paradigm shift by which, having truly purged our interpretation of every residue of the metaphysics Heidegger sought to overcome, philosophy is

\footnotetext{
${ }^{4}$ See especially M. Heidegger, "The Thing," in Bremen and Freiburg Lectures, trans. A. Mitchell (Bloomington: Indiana University Press, 2012), pp. 16-20. Further development of the thought that this later Heidegger remains a phenomenologist would have to attend to the fact that the fourfold is also the essence of language, insofar as it gathers in the manner explored by Heidegger.

5 D. Franck, Heidegger et le christianisme. L'explication silencieuse (Paris: P.U.F., 2004).

${ }^{6}$ R. Schürmann, Heidegger on Being and Acting: From Principles to Anarchy (Bloomington: Indiana University Press, 1990).
} 
brought back to concentrate on the intimacy of Being and meaning that preoccupies Heidegger throughout his way. But in Richard Capobianco's "Reaffirming the 'Truth of Being'," the paradigm change would appear to center phenomenological research on Dasein, indeed as clearing, in a manner that does not sit neatly with important passages in which Heidegger seems to require thinking to await the initiative of Being. If on Sheehan's account this latter sort of reading is in danger of hypostasizing Being, according to Capobianco Sheehan's reading flirts with handing Heidegger himself over to Seinsvergessenheit. Much of this comes down to a debate over quite what Heidegger has meant by Ereignis, at once integral to an enriched conception of what Sein und Zeit probes as Dasein and yet also integral to a sense in which Being gives itself in the meaningful presence of things. Ereignis is a central theme of several of the essays appearing here.

The remaining essays are arranged somewhat chronologically, as regards the texts on which they tend to concentrate. In "Retrieving Phronesis. Heidegger on the Essence of Politics," Gregory Fried explores the political philosophy, with its difficulties and its lacunae, that appears while Heidegger develops his conception of Ereignis. I have already touched on the thought that Heidegger does not wish to spare philosophy from the conditions of the polemos that it has had to recognize; Fried follows the thread along which he attempts to nonetheless preserve the critical force of the logos. This involves Heidegger in the unsteady attempt to recognize the historicity of meaning while nonetheless seeking essences, in the sense of persistent and irreducible conditions. In turn, it suggests that the 'essences' in question-of a people, most notably - are exposed to a politics that must be without ground, whereupon matters of value and commitment must await a decision without guiding principles. Taking Heidegger's cue, Fried exposes this problem to some close reflection on tragedy. But unlike Heidegger, he carries the reflection through to Aristotle, in whose notion of phronesis we find important resources for a theory of decision capable of summoning rational guidance that does not simply rest on a metaphysical foundation.

In "Heidegger's Imageless Saying of the Event," Daniela Vallega-Neu follows Heidegger on his way into concentrated meditation on Ereignis, and not without briefly reminding us of the political stakes: beginning in the mid-1930s, Heidegger seems to distinguish between public writing that is constrained to recognize and free itself from the metaphysical trappings of the genre and a private writing that is generally more poetic insofar as it is capable of registering and transmitting insight without such concerns. Valega-Neu takes up Heidegger's 1941/42 text entitled Das Ereignis (The Event; a review of the English translation appears in this journal issue). After some remarks on the better-known Contributions to Philosophy. On Ereignis, she moves to the newer texts committed to the same central theme, and reviews their relationship. As we have already seen, Heidegger's notion of "Ereignis" lies at the heart of what appears as the end of metaphysics comes to pass: in short, the abyss of the truth of Being (or "beyng," in these texts). This becomes Heidegger's perspective from which to rethink the history of Being, and indeed the inception of the history of Being, such as appears in the rise and passing of metaphysics. 
Holger Schmid's "Praeteritio Dei" ([not-]saying of God) is an intricate account of the filiation between the thinker's pursuit of the meaning of Being and the question of the divine. Heidegger's most familiar themes touch on both of these themes at once: whether the end of metaphysics is developed in terms of a call to think through the ontological difference or according to a critique of onto-theology, the metaphysics in question is generally associated with Christian thought in a manner that implies the exclusion of God from philosophy. Yet these very arguments call for an extended encounter with Greece, where, after all, one must recognize the inception of the history of Being. And in figures from whom Heidegger seeks help to get closest to that inception-Sophocles, for example, or Parmenides - the texts that invite the thinking of Being also honor the gods.

Heidegger perhaps nowhere summons the early Greeks more insistently than in his 1942/43 course on the Parmenides. In "The Secret According to Heidegger and The Purloined Letter by Poe," Rudolf Bernet concentrates on the conception of the secret that is not only the text's "center of gravity," but also the key to a proper understanding of what is meant there (and elsewhere) by aletheia, and indeed any number of closely related themes. According to Heidegger, the Greek experience of truth as unconcealment includes a positive dimension of secrecy, of mystery ingredient to whatever comes forth to be seen. Such mystery is no more a riddle to be solved than is the charm of beings reducible to their susceptibility to measurement and control. Heidegger's account of the secret is far-reaching but brief. In order to develop it further, and to unlock its promise for theories of oblivion, memory, and gift, Bernet turns to Poe's remarkable short story about a secret and its manner of evading discovery, "The Purloined Letter."

Bret Davis's "Returning the World to Nature" is centered on the texts entitled Country Path Conversations (1944/45), in which Heidegger brings together a range of earlier explorations of what he considers the Greeks experience as physis and what in German he renders as Natur. As Heidegger's understanding of nature deepens, so too does his understanding of world. Nature is thought increasingly as an abundance in which we find ourselves, and which exceeds the profile turned toward us as world. In order to realize nature and world in this manner, Heidegger also had to free his own thinking from an earlier tendency toward conceiving world only within a transcendental-horizontal projection still influenced by a will to comprehend. The self-critique by which he does so goes hand-in-hand with the revised conceptions of world and nature. As metaphysics truly passes, thinking is no longer guided by willing, whereupon the thinker is released into nature and nature becomes the horizon within which to witness what Heidegger calls the "worlding of world."

The final contribution to this journal issue is Françoise Dastur's "Time, Event and Presence in the Late Heidegger." In fact, the essay involves considerably more than the title suggests, since Dastur sometimes ranges back all the way to Sein und Zeit. This permits her not only to gain some perspective on any number of difficulties in some of Heidegger's later pronouncements, but also to make a show clearly that the way of Heidegger's thinking is without a definitive exit-if by this one means final resolution of a problem, or conclusion of a finite task. This becomes clear especially after 1930s, when Heidegger begins to observe, according to 
various formulations, that the oblivion of Being cannot be corrected and overcome. Rather, since Being remains concealed in its own unconcealment, Being must be thought in and as presencing rather than somehow through or around it. According to Heidegger, classical metaphysics has restricted Being to presence, in which case it attends only to beings. What metaphysics thus fails to think is presencing as being given from beyond limitation to the present. What can be the implication of this realization of givenness? By 1973, in his last seminar, Heidegger makes plain that if it is to constitute an awakening from the oblivion of Being, then in fact philosophy will have conducted us finally to a tautology whose meaning for us is both profound and uncertain. Ereignis ereignet: understood in full context, this means only that Being is, and the thinker can only receive what is thus given to be seen.

It is a pleasure to include in this issue of the Continental Philosophy Review Thomas Sheehan's painstaking bibliography "Heidegger's Gesamtausgabe Volumes and Their English Translations (as of April 2014)." Quite simply, Anglophone scholarship on Heidegger is immediately in his lasting debt.

This issue also includes excellent reviews by Jeffrey Powell, Christopher Merwen, Will Britt, Tobias Keiling, and Jacob Rump. It goes without saying that the dissemination and interpretation of Heidegger's work remains active and robust. 